\title{
Antioxidant activity of anthocyanins from quixabeira (Sideroxylon obtusifolium) fruits
}

FIGUEIREDO, F.J.'; LIMA, V.L.A.G. ${ }^{2}$

Universidade Federal de Sergipe/UFS - Rua Padre Álvares Pitangueira, 253, Centro Cidade, Lagarto, SE, Brasil; CEP: 49400-000 2Universidade Federal Rural de Pernambuco/UFRPE - Av. Dom Manoel de Medeiros, s/n, Dois Irmãos, CEP: 52171-900, Recife, PE, Brasil. *Autor para correspondência: veraarroxela@hotmail.com

\begin{abstract}
The fruits of Sideroxylon obtusifolium T.D. Penn. are small berries which have dark purple skin color at maturity due the anthocyanins presence. Therefore, the aim of this research was to evaluate the antioxidant activity of anthocyanins from mature fruits which were obtained at a semi-arid region of Paraiba/BR. In addition, the total anthocyanins content was measured by the $\mathrm{pH}$ differential method. The anthocyanins were purified by solid-phase extraction (SPE) using C18 Sep-Pak cartridges and submitted to antioxidant activity determined by scavenging 2,2-diphenyl-1-picrylhydrazyl (DPPH·). The butylated hydroxytoluene (BHT) was the positive control and the results were expressed as $\mathrm{DPPH}$ - scavenging activity (\%). Anthocyanins content were higher in the husks (236.15 mg cyanidin-3-glucoside $100 \mathrm{~g}^{-1} \mathrm{fw}$ ) than in the pulp (30.49 mg cyanidin-3-glucoside $100 \mathrm{~g}^{-1} \mathrm{fw}$ ). The results showed that the potential free radical scavenging grew with the increase of concentration used and the reaction time. The ability of the anthocyanins in scavenging the free radical was statistically greater than the BHT one. The anthocyanins which were present in this fruit may supply substantial dietary source of antioxidant that may promote health and produce disease prevention effects or that could be applied in food industry as a good source of natural pigments.
\end{abstract}

Keywords: quixaba, native fruits, natural pigment, $\mathrm{DPPH} \cdot$ radical

RESUMO: Atividade antioxidante de antocianinas de frutos de quixabeira (Sideroxylon obtusifolium). Os frutos da Sideroxylon obtusifolium TD Penn., são bagas pequenas que, quando maduras, apresentam a coloração roxo-escuro devido à presença de antocianinas. Assim, o objetivo desta pesquisa foi avaliar a atividade antioxidante das antocianinas desses frutos maduros obtidos da região do semiárido da Paraíba/BR. Além disso, o teor de antocianinas total foi quantificado pelo método de $\mathrm{pH}$ diferencial. As antocianinas foram purificadas por extração em fase sólida (EFS) utilizando cartuchos Sep-Pak C18 e submetidas à avaliação da atividade antioxidante por meio da capacidade de sequestrar o radical DPPH. Butil-hidroxitolueno (BHT) foi utilizado como controle positivo e os resultados foram expressos como percentual de sequestro de radical livre. Os resultados demonstraram que o teor de antocianinas presente nas cascas foi maior $\left(236,15 \mathrm{mg}\right.$ de cianidina-3-glicosídeo $100 \mathrm{~g}^{-1}$, peso fresco) do que na polpa (30,49 mg de cianidina-3- glicosídeo $100 \mathrm{~g}^{-1}$, peso fresco) e que o percentual de sequestro de radical livre aumentou com o aumento da concentração utilizada e o tempo de reação. A habilidade das antocianinas em sequestrar o radical livre foi estatisticamente superior à do BHT. As antocianinas presentes nesta fruta podem fornecer fonte dietética significativa de antioxidantes que podem promover a saúde e produzir efeitos de prevenção de doenças ou ser aplicada na indústria de alimentos como uma boa fonte de pigmentos naturais.

Palavras-chave: quixaba, frutas nativas, pigmento natural, radical DPPH:

\section{INTRODUCTION}

The Sideroxylon obtusifolium (Humb. ex Roem. \& Schult.) T.D. Penn. is a medicinal plant species native from the caatinga. The
'Caatinga' ecosystem covers almost 1 million $\mathrm{km}^{2}$ in northeastern Brazil. Its characteristic xerophilous vegetation is affected by long and irregular droughts,

Recebido para publicação em 02/04/2014 
high temperatures and elevated UV radiation (Desmarchelier et al., 1999).

This species presents the following scientific synonymy; Bumelia sartorum Mart, Bumelia obtusifolium Roemer \& Schut and Bumelia rotundifolia Schut (Beltrão et al., 2008). It is known as "quixaba" or "rompe-gibão" (Desmarchelier et al., 1999) but also by many others different common names as described by Paulino et al. (2011).

According to Albuquerque et al. (2007), the extracts from the bark of the stems and the leafs are prepared to medicinal purpose and used to treat general inflammations, injuries, blows, woundhealing, cleansing uterine and wounds. Ferreira Júnior et al. (2011) reported that for inflammation from contusion, the species Sideroxylon obtusifolium may act on substances such as prostaglandins, leukotrienes, interleukins and tumor necrosis factor to alleviate the symptoms of "pooled blood" and "pain". This information is important for guiding future pharmacological studies on the possible mechanisms by which plants may be used to treat inflammation.

Due to their intense use and lack of cultivation, its occurrence in the natural habitat became rare. In this sense, Beltrão et al. (2008) developed study in order to get information about the biomass production of this native species using the techniques of plant tissues culture.

The quixabeira fruits are small berries which can be eaten fresh and have dark purple skin color at maturity (Silva et al., 2012). According to Aroucha et al. (2010) this color is due to anthocyanins presence. These compounds belong to the flavonoids class (Macheix et al., 1990) and they are responsible for the shiny orange, pink, red, violet and blue colors in the flowers, fruits and others parts of plants (Escribano-Bailón et al., 2004; Castañeda-Ovando et al., 2009; Murthy et al., 2012; Jiang et al., 2013).

The health-benefit properties of natural pigments have been focused by many works, especially those of anthocyanins. In the last decades, research on anthocyanins has intensified by the increasing evidence that anthocyanins have beneficial health effects. Based upon many studies it has been suggested that anthocyanins protect against cardiovascular diseases, some types of cancer, obesity, diabetes, among others, all of which are more or less associated with their potent antioxidant property (Shipp \& Abdel-Aal, 2010; He \& Giusti, 2010; Lucioli, 2012).

Brazil is a country with great biodiversity, however there is still a considerable lack of knowledge regarding to several native fruits. Previous studies have focused mainly on the chemical composition (Garrido et al., 2007; Aroucha et al., 2010) or on characterize morphologically internal and external structures of fruits and seeds of Sideroxylon obtusifolium (Silva et al., 2012). However, as far as we know, no studies on antioxidant activity of anthocyanins purified from this fruit have been published. Therefore, the aim of this research was to assay the DPPH radical scavenging activity of anthocyanins from Sideroxylon obtusifolium fruits.

\section{MATERIALS AND METHODS \\ Chemicals}

Butylated hydroxytoluene (BHT), and 2,2-diphenyl-1-picrylhydrazyl (DPPH) were purchased from Sigma Chemical Co. (St. Louis, $\mathrm{MO})$. All other reagents were of analytical grade.

\section{Plant Material}

The fruits used in this study were from the "Sítio Barrocas", located in the municipality of Soledade ( $7^{\circ} 03^{\prime} 30^{\prime \prime} \mathrm{S}$ and $\left.36^{\circ} 21^{\prime} 47^{\prime \prime} \mathrm{W}\right)$, the semiarid region of Paraíba which is characterized by the caatinga vegetation. According to CPRM (2005), Soledade has an area of $560 \mathrm{~km}^{2}$, an approximate altitude of 521 meters and far $165.5 \mathrm{~km}$ from the capital of Paraíba.

The mature quixaba fruits $(1,000 \mathrm{~g})$ were manually harvested during March 2012 from different trees and selected for uniformity of purple color. They were packed in polyethylene bags, stored under refrigeration and subsequently transported to the Physical-chemical Food Analysis Laboratory of the Home Sciences Department of the Federal Rural University of Pernambuco (UFRPE), where the experiments were performed.

Fruits were sorted to discard overripe or damaged berries. Parts of these fruits were used to quantify the total anthocyanins in the pulp and in the husks and the other to obtain the purified anthocyanins.

\section{Anthocyanins extraction}

The anthocyanins were extracted according to Rodriguez-Saona \& Wrolstad (2001). In brief, the samples were blended with $70 \%$ (v/v) aqueous acetone with $0.01 \% \mathrm{HCl}$ and filtered. The filter cake residues were reextracted with acetone until a clear solution was obtained. Filtrates were combined, shaken in a separator funnel with 2 volumes of chloroform, and stored overnight at $4^{\circ} \mathrm{C}$. The addition of chloroform resulted in phase separation between the aqueous portion (which contains anthocyanins, phenolics, sugars, organic acids, and other watersoluble compounds) and the bulk phase (which contains lipids, carotenoids, chlorophyll pigments, and other nonpolar compounds). The nonpolar phase was discarded, and the upper aqueous layer was collected and residual acetone removed using 
a rotary evaporator at $40^{\circ} \mathrm{C}(5-10$ minutes $)$, and then the anthocyanins aqueous extract (AcyE) was stored at $-18^{\circ} \mathrm{C}$ until analysis.

\section{Total Monomeric Anthocyanin by the pH- Differential Method}

The total anthocyanins content was quantified separately in the pulp and in the husks. The pulp was manually removed and separated from the husks with the aid of a stainless steel knife and stored at $-18^{\circ} \mathrm{C}$ until analysis. All further procedures were performed under reduced light conditions.

The anthocyanins were extracted according to Rodriguez-Saona \& Wrolstad (2001) and the monomeric anthocyanin pigment content of the aqueous extracts was determined using the $\mathrm{pH}$ differential method (Giusti \& Wrolstad, 2001).

The anthocyanins aqueous extract (AcyE) were appropriately diluted with $0.025 \mathrm{M}$ potassium chloride buffer, $\mathrm{pH} 1.0$ and $0.4 \mathrm{M}$ sodium acetate buffer, $\mathrm{pH}$ 4.5. After $15 \mathrm{~min}$ to equilibrate these dilutions the anthocyanins content was measured at $510 \mathrm{~nm}$ and $700 \mathrm{~nm}$ using a Shimadzu UV$1650 \mathrm{PC}$ spectrophotometer and a $1 \mathrm{~cm}$ path length disposable cell. The absorbance $(A)$ of the diluted sample was calculated as follows:

$$
A=\left(A_{\lambda \text { vis-max }}-A_{700}\right)_{\mathrm{pH} 1,0}-\left(A_{\lambda \text { vis-max }}-A_{700}\right)_{\mathrm{pH} 4,5}
$$

The monomeric anthocyanin concentration in the original sample was calculated using the following formula:

Total Monomeric Anthocyanin $=\frac{A \times M W \times D F \times 1000}{\varepsilon \times 1}$

The total monomeric anthocyanin content was calculated as milligrams cyanidin-3-glucoside $100 \mathrm{~g}^{-1}$ fresh weight using a molecular weight (MW) of $449.2 \mathrm{~g} \mathrm{~mol}^{-1}$, appropriated dilution factor (DF) and molar extinction coefficient $(\varepsilon)$ of $26900 \mathrm{~L} \mathrm{~cm}^{-1} \mathrm{~mol}^{-1}$.

\section{Extraction}

Anthocyanin Purification by Solid Phase

After the seeds were removed, the husks together with the pulp were crushed in a home blender with no addition of water and stored at $-18^{\circ} \mathrm{C}$ until analysis. This pulp (pulps with husks) was used to obtain the purified anthocyanins.

The anthocyanins were extracted following the procedures above described and the anthocyanins aqueous extract (AcyE) was purified according to Rodriguez-Saona \& Wrolstad (2001). In brief, the anthocyanins aqueous extract (AcyE) (5 to $10 \mathrm{~mL}$ ) was passed through C18 Sep-Pak cartridges (Plus, $360 \mathrm{mg}$, Waters Associates, Milford, MA) previously activated with methanol followed by $0.01 \%$ aqueous $\mathrm{HCl}$. The anthocyanins and other polyphenolics were adsorbed onto the Sep-Pak column while sugars and acids and other water-soluble compounds were removed by washing the column with $0.01 \%$ aqueous $\mathrm{HCl}$. The phenolic compounds other than anthocyanins were removed from the column by washing with ethyl acetate and anthocyanins were subsequently eluated with methanol containing $0.01 \% \mathrm{HCl}(\mathrm{v} / \mathrm{v})$. The methanolic extract was then stored at $-18^{\circ} \mathrm{C}$ for further procedures. All procedures were performed under reduced light conditions.

\section{Precipitation of anthocyanins}

The anthocyanins were precipitated according to Espín et al. (2000). The methanolic extracts were concentrated under vacuum to dryness. The diethyl ether was added to the residue in order to obtain the precipitated pigments. The dried anthocyanins (ACY) were kept in small dark vials, and stored at $4^{\circ} \mathrm{C}$ for further analysis.

Determination of antioxidant activity using the 2,2-Diphenyl-1-picrylhydrazyl (DPPH-) radical scavenging method

Radical scavenging activity of extracts was measured by slightly modified method of BrandWilliams et al. (1995) as described below. Briefly, the anthocyanins powders were solubilized in methanol and $0.1 \mathrm{ml}$ with different concentrations (1.0 and $0.5 \mathrm{mg} \mathrm{mL}^{-1}$ ) was mixed into screw-cap test tubes wrapped in aluminum foil containing $5.9 \mathrm{ml}$ of 0.1 $\mathrm{mM}$ DPPH methanol solution.

The final concentrations in the cuvette were 16.95 and $8.47 \mu \mathrm{g} \cdot \mathrm{mL}^{-1}$, respectively. A methanol solution of BHT (butylated hydroxytoluene) was used as a positive control, and it was prepared to obtain the same final concentrations as the anthocyanins solutions. The reaction mixtures were shaken, kept in the dark at ambient temperature $\left(23 \pm 1^{\circ} \mathrm{C}\right)$, and the decrease in absorbance at $515 \mathrm{~nm}$ was measured at $5,15,30$, and 60 minutes using a Shimadzu UV1650PC spectrophotometer.

Inhibition of the DPPH radical by the samples was calculated according to the following formula (Miliauskas et al., 2004):

DPPH scavenging activity $(\%)=\left[A_{B}-A_{A} / A_{B}\right] \times 100$,

where; $A_{B}=$ absorption of blank sample ( $t$ $=0$ minute); $A_{A}=$ absorption of tested anthocyanins solutions or absorption of tested BHT solutions $(t=$ for each different time).

\section{Statistical Analyses}

The experimental results were expressed as mean \pm standard deviation of triplicate measurements 
and the results were processed using Statistic software package version 6.0 (StatSoft, Inc.). The differences between the means were analyzed by Analysis of Variance (ANOVA) and Tukey test in order to compare the antioxidant activity of the anthocyanins and the BHT. Differences at $p<0.05$ were considered to be significant.

\section{RESULTS AND DISCUSSION Total anthocyanins content}

Total anthocyanins content are showed in Figure 1. Anthocyanins were found in higher

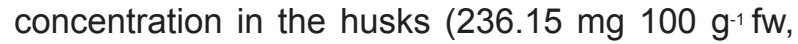
expressed as cyanidin-3-glucoside equivalent) than in

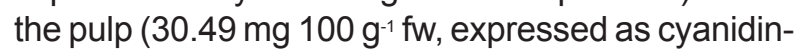
3-glucoside equivalent). Gross (1987) confirms these results by stating that the anthocyanins are located mainly in husks of fruits. Lima et al. (2002) reported that in mature Surinam cherry these pigments are also more concentrated in the husks than in the pulp,

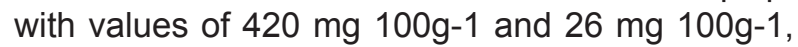
respectively.

Other fruits also contain significant amounts of anthocyanins. Contessa et al. (2013) reported that in fruit species grown in Northwest Italy the highest anthocyanin content was found in black mulberry (341.53 mg $100 \mathrm{~g}^{-1} \mathrm{fw}$, expressed as cyanidin-3glucoside equivalent), followed by black currant (224.79 mg $100 \mathrm{~g}^{-1} \mathrm{fw}$, expressed as cyanidin-3glucoside equivalent), blueberry (222.74 ${\mathrm{mg} 100 \mathrm{~g}^{-1}}^{-1}$ $\mathrm{fw}$, expressed as cyanidin-3-glucoside equivalent)

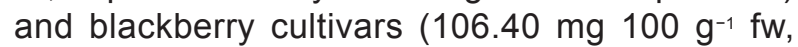
expressed as cyanidin-3-glucoside equivalent). Recently, Brazil has become a blueberry producer with a small production concentrated in the south and southeastern regions of the country, and Rodrigues et al. (2011) reported that in blueberry cultivars (Vaccinium sp.) grown in Brazil the anthocyanins concentration ranged from 40.62 to $378.31 \mathrm{mg}$ $100 \mathrm{~g}^{-1} \mathrm{fw}$, expressed as cyanidin-3- glucoside equivalent.

According to Macheix et al. (1990) fruits rich in anthocyanins (> $200 \mathrm{mg}^{100-1} \mathrm{~g}$ ) are strongly colored berries and present deep purple color or black. Mature quixaba shows this characteristic color and its husks can be considered a good source of anthocyanins.

\section{Determination of antioxidant activity using} the 2,2-Diphenyl-1-picrylhydrazyl (DPPH) radical scavenging method

$\mathrm{DPPH}$ is a free radical compound and it is widely used to test the ability of compounds to act as free radical scavengers or hydrogen donors, and to evaluate antioxidant capacity. The reduction of DPPH by antioxidant compounds results in a loss of absorbance and the degree of solution discoloration indicates the scavenging efficiency of the added substance. When DPPH reacts with an antioxidant compound, which can donate hydrogen atoms, it is reduced and its color changes from deep-violet to light-yellow. The extent of the reaction will depend on the antioxidant's hydrogen donating ability.

Many authors have used different reaction times such as 5 minutes (Rodrigues et al., 2011), 15 minutes (Nakajimaet al., 2004), 30 minutes (Sharma \& Bhat, 2009), 60 min (Proestos et al., 2013) or 10, 20 and 30 minutes in the same assay (Ahmad et al., 2013).

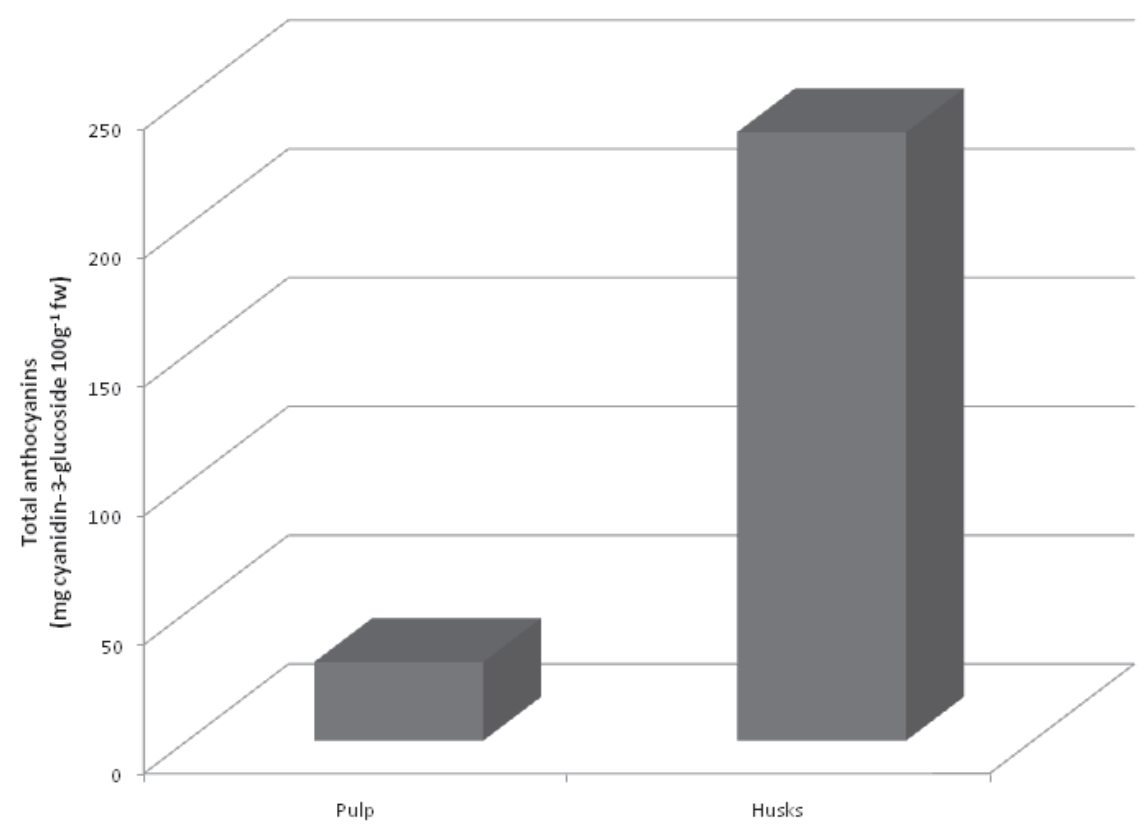

FIGURE 1. Total anthocyanins content in the pulp and husks of quixaba fruits

Rev. Bras. PI. Med., Campinas, v.17, n.3, p.473-479, 2015. 
TABLE 1. DPPH radical scavenging activity (\%) of anthocyanins from mature quixaba fruits and BHT

\begin{tabular}{|c|c|c|c|c|}
\hline \multirow{2}{*}{$\begin{array}{l}\text { Samples } \\
\text { (concentration) }\end{array}$} & Reaction time & \multirow[b]{2}{*}{$15 \mathrm{~min}$} & \multirow[b]{2}{*}{$30 \mathrm{~min}$} & \multirow[b]{2}{*}{$60 \mathrm{~min}$} \\
\hline & $5 \mathrm{~min}$ & & & \\
\hline ACY $(8.47 \mu \mathrm{g} \mathrm{mL-1})$ & $44.35 \pm 0.63$ вв & $52.61 \pm 1.89$ bA & $58.04 \pm 2.41 \mathrm{bA}$ & $62.78 \pm 2.49 \mathrm{bA}$ \\
\hline $\operatorname{ACY}\left(16.95 \mu \mathrm{g} \mathrm{mL}^{-1}\right)$ & $70.15 \pm 2.43 \mathrm{ac}$ & $76.72 \pm 1.76$ ав & $84.55 \pm 1.69$ аА & $90.45 \pm 1.58$ \\
\hline $\mathrm{BHT}\left(8.47 \mu \mathrm{g} \mathrm{mL}^{-1}\right)$ & $16.93 \pm 0.06 \mathrm{cD}$ & $24.26 \pm 0.98 d c$ & $33.33 \pm 1.40 \mathrm{~dB}$ & $46.55 \pm 1.99 \mathrm{cA}$ \\
\hline BHT $\left(16.95 \mu \mathrm{g} \mathrm{mL}^{-1}\right)$ & $19.75 \pm 1.76 \mathrm{~d}$ & $30.94 \pm 1.45 c$ & $44.24 \pm 1.12$ св & $61.80 \pm 1.15 \mathrm{bA}$ \\
\hline
\end{tabular}

Values are means \pm standard deviations. Means values with the same lowercase letters in the same column and means values with the same capital letters in a row are not significantly different by Tukey's test $(P>0.05)$. ACY: anthocyanins; BHT: butylated hydroxytoluene

The antioxidant capacity of anthocyanins purified from quixaba and BHT at both concentrations is shown in Table 1. It can be observed that the potential free radical scavenging increased with increasing concentration and reaction time.

Duan et al. (2007) investigated antioxidant property of anthocyanins extracted and purified from litchi fruit pericarp using DPPH method, and found that $\mathrm{DPPH}$. radical scavenging activity increased with the increase of anthocyanin content. Ahmad et al. (2013) also reported that DPPH radical scavenging activity increased with incubation period increase.

It could be easily observed that the anthocyanins exhibited notable DPPH radical scavenging activity as presented in Table 1. After 5 minutes of reaction time and at the highest concentration tested, the anthocyanins purified from quixaba exhibited significantly the highest $\mathrm{DPPH} \cdot$ radical scavenging capacity $(70.15 \%)$. Kähkönen et al. (2003) demonstrated that after 4 minutes of reaction time and using almost the same concentration tested, the anthocyanins isolated from blackberry presented the most efficient DPPH radical scavenging capacity $(58 \%)$, followed by bilberry (52\%) and cowberry (36\%). The anthocyanin extracts of rabbiteye blueberry, black currant, chokeberry, and elderberry showed relatively similar activities, varying approximately from 45 to $55 \%$ after 5 minutes reaction time and at $1 \mathrm{mg} \mathrm{mL}^{-1}$ by DPPH. test (Nakajima et al., 2004).

After 5 minutes of reaction time and at concentration tested $(8.47 \mu \mathrm{g} \mathrm{mL}-1)$, the $\mathrm{DPPH}$. radical scavenging capacity of the anthocyanins purified from quixaba (44.35\%) was statistically higher than BHT. Kähkönen et al. (2003) using almost the same concentration and after 4 minutes of reaction time, reported that anthocyanin isolates from blackberry, bilberry, and cowberry showed that $\mathrm{DPPH} \cdot$ radical scavenging capacities were 38,38 , and $25 \%$, respectively.

In this study, BHT showed significantly the lowest value after 5 minutes of reaction time at both concentrations tested (Table 1). The percentages of radical scavenging were 16.93 and $19.75 \%$ at 8.47 and $16.95 \mu \mathrm{g} \mathrm{mL}^{-1}$ concentrations, respectively. Bondet et al. (1997) reported that BHT reacts very slowly with $\mathrm{DPPH}$ reaching a steady state within 5 hours. Other authors also reported that BHT had low activity by the DPPH method (Rufino et al., 2009; Sharma \& Bhat, 2009). Duan et al. (2007) investigated antioxidant property of anthocyanins extracted and purified from litchi fruit pericarp and reported that at $50 \mu \mathrm{g} \mathrm{mL}^{-1}$ and after $30 \mathrm{~min}$, the scavenging effects were $91.3 \%$ and $9.73 \%$ for anthocyanins and $\mathrm{BHT}$, respectively. Thus, the more rapidly the absorbance decreases and consequently the percentage radical scavenging increases, the more potent is the antioxidant activity of the compound in terms of hydrogen donating ability.

After 60 min of reaction time and at the highest concentration tested (Table 1), the anthocyanins purified from quixaba still exhibited significantly the highest DPPH radical scavenging capacity $(90.45 \%)$. Only at 60 min of reaction, BHT solution at $16.95 \mathrm{\mu g} \mathrm{mL}^{-1}$ concentration did not differ statistically to the anthocyanin solution at $8.47 \mu \mathrm{g}$ $\mathrm{mL}^{-1}$ concentration.

Independently of the reaction time, the anthocyanin solution at $16.95 \mu \mathrm{g} \cdot \mathrm{mL}^{-1}$ concentration showed the highest free radical scavenging capacity. Lima et al. (2011) reported that anthocyanins purified from 12 acerola genotypes were assessed for antioxidant activity and after 60 minutes of reaction time and at $16.95 \mathrm{~g} \mathrm{~mL}^{-1}$ concentration, the DPPH. radical scavenging capacity ranged from 65.59 to 93.96\%.

The kinetic behavior of the anthocyanins and BHT against DPPH can be observed in Figure 2. According to Brand-Williams et al. (1995) the evolution of the different reaction kinetics depends on the nature of the antioxidant being tested.

In this study the scavenging of the free radical by each compound studied resulted in behavior with similar pattern of $\mathrm{DPPH}$ radical scavenging (\%) versus time. It was evidenced that $\mathrm{DPPH} \cdot$ scavenging can be separated in two parts; a first rapid one during the first $30 \mathrm{~min}$ and a second in which the radical was being scavenged at a very slow rate.

According to Rufino et al. (2009) the oxidation reaction is truly a second-order reaction since two species react to form one or more oxidation 


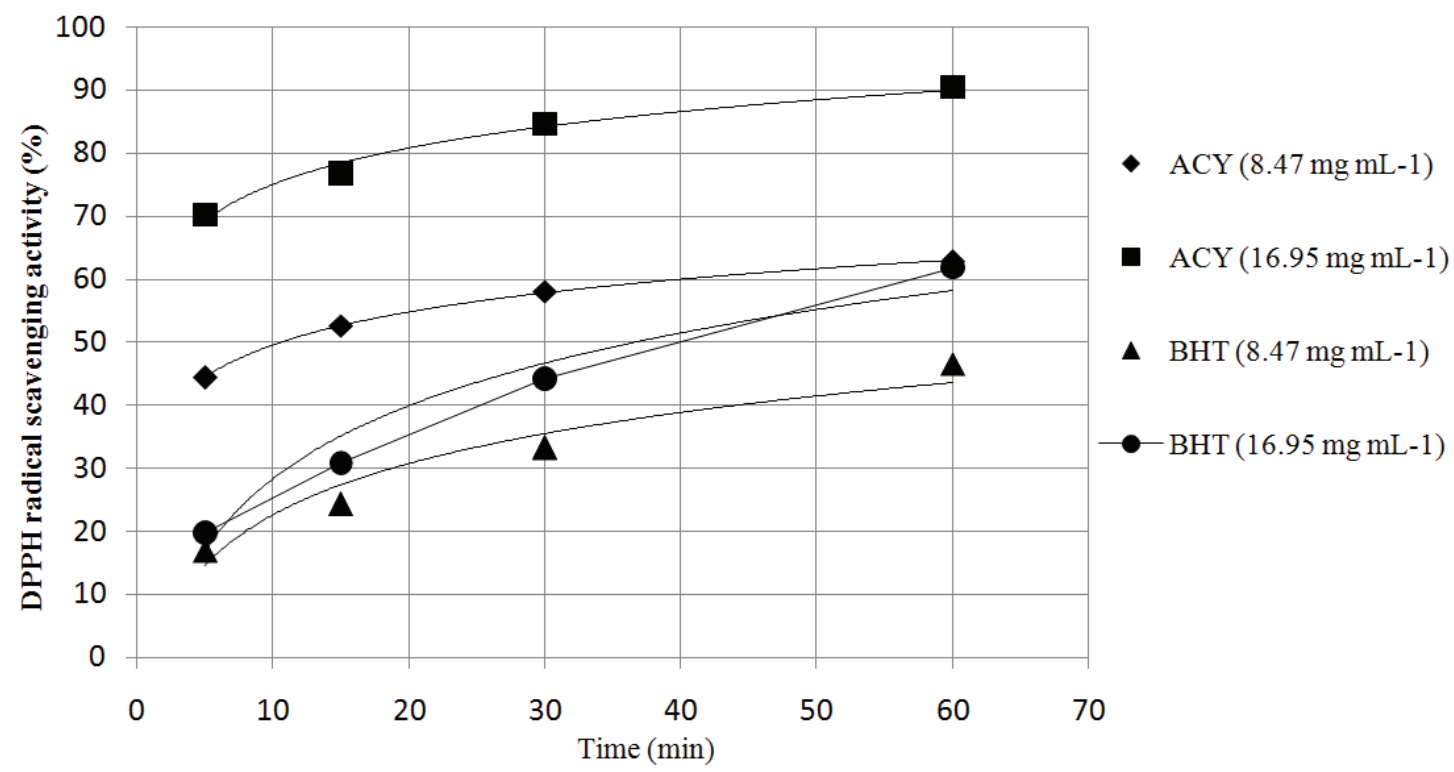

FIGURE 2. Kinetics of antioxidant activity of ACY (anthocyanins) and BHT (butylated hydroxytoluene) at 16.95 $\mu \mathrm{g} \mathrm{mL}-1$ and at $8.47 \mu \mathrm{g} \mathrm{mL}^{-1}$ concentration using $\mathrm{DPPH} \cdot$ method.

products. The reaction may be assumed as a pseudo-first order reaction if one of the reactants is in excess, as assumed by Brand-Williams et al. (1995).

There was positive linear correlation between $\mathrm{DPPH}$ radical scavenging rate and the time of reaction at first, while the trend slowed down as the time of reaction (Figure 2). Burdulis et al. (2009) reported that antioxidant activity in bilberry and blueberry fruits and their skins had similar patterns of behavior in response to time and that with an increase of time the amount of quenched free radical was increased proportionally. It was found that equilibrium, when amount of inactivated free radical is stable, was attained after $30 \mathrm{~min}$. The DPPH scavenging activity of three varieties of cultivated highbush blueberries and the two types of wild blueberries extracts were assessed by Bunea et al. (2011) and kinetic curves similar to the present study were reported.

\section{CONCLUSIONS}

The results provided evidence that anthocyanins from quixaba presented high $\mathrm{DPPH}$. free radical scavenging potential which increased with the increase of concentration used and reaction time and showed statistically greater free radical scavenging ability than the BHT ones. The anthocyanins present in this fruit may supply substantial dietary source of antioxidant which may promote health and produce disease prevention effects or could be applied in food industry as a good source of natural pigments.

\section{REFERENCES}

AHMAD, N. et al. DPPH free radical scavenging activity and phenotypic difference in hepatoprotective plant (Silybum marianum L.). Toxicology and Industrial Health, v.29, n.5, p.460-467, 2013.

ALBUQUERQUE, U.P. et al. Medicinal and magic plants from a public market in northeastern Brazil. Journal of Ethnopharmacology, v.110, n.1, p.76-91, 2007.

AROUCHA, E.M.M. et al. Características químicas de frutos da quixabeira. Revista Verde de Agroecologia e Desenvolvimento Sustentável, v.5, n.2, p.5-8, 2010.

BELTRÃO, A.E.S. et al. In vitro biomass production of Sideroxylon obtusifolium (Roem \& Schult). Revista Brasileira de Farmacognosia, v.18, n. suppl., p. 696698, 2008.

BONDET, V. et al. Kinetics and mechanisms of antioxidant activity using the DPPH free radical method. Lebensmittel-Wissenschaft \& Technologie, v.30, n.6, p. 609-615, 1997.

BRAND-WILLIAMS, W. et al. Use of a free method to evaluate antioxidant activity. LebensmittelWissenschaft \& Technologie, v.28, n.1, p.25-30, 1995.

BUNEA, A. et al. Comparative polyphenolic content and antioxidant activities of some wild and cultivated blueberries from Romania. Notulae Botanicae Horti Agrobotanici, v.39, n.2, p.70-76, 2011.

BURDULIS, D. et al. Comparative study of anthocyanin composition, antimicrobial and antioxidant activity in bilberry (Vaccinium myrtillus L.) and blueberry (Vaccinium corymbosum L.) fruits. Acta Poloniae Pharmaceutica - Drug Research, v.66, n.4, p.399408, 2009.

CASTAÑEDA-OVANDO, A. et al. Chemical studies of anthocyanins: a review. Food Chemistry, v.113, n.4, p. 859-871, 2009. 
CONTESSA, C. et al. Total antioxidant capacity and total phenolic and anthocyanin contents in fruit species grown in Northwest Italy. Scientia Horticulturae, v.160, n.27, p.351-357, 2013.

CPRM. Serviço Geológico do Brasil. Projeto cadastro de fontes de abastecimento por água subterrânea, estado da Paraíba. Diagnóstico do município de Soledade. Organizado [por] BELTRÃO, B.A.; MORAIS, F.; MASCARENHAS, J.C.; MIRANDA, J.L.F.; SOUZA JUNIOR, L.C.; MENDES, V.A. Recife: CPRM/ PRODEEM, 2005. 10p. Disponível em: http://www. cprm.gov.br/rehi/atlas/paraiba/relatorios/SOLE204.pdff. Acesso em 28 mar. 2014.

DESMARCHELIER, C. et al. Antioxidant and free radical scavenging activities in extracts from medicinal trees used in the 'Caatinga' region in northeastern Brazil. Journal of Ethnopharmacology, v.67, n.1, p.69-77, 1999.

DUAN, X. et al. Antioxidant properties of anthocyanins extracted from litchi. Food Chemistry, v.101, n.4, p.1365-1371, 2007.

ESCRIBANO-BAILÓN, M.T. et al. Anthocyanins in cereals. Journal of Chromatography A, v.1054, n.1-2, p.129-141, 2004.

ESPÍN, J.C.et al. Anthocyanin-based natural colorants: a new source of antiradical activity for foodstuff. Journal of Agricultural Food Chemistry, v.48, n.5, p.15881592, 2000.

FERREIRA JÚNIOR, W.S. et al. Resilience and adaptation in the use of medicinal plants with suspected antiinflammatory activity in the Brazilian Northeast. Journal of Ethnopharmacology, v.138, n.1, p.238-252, 2011.

GARRIDO, M.S. et al. Características física e química de frutos de quixaba (Sideroxylon obtusifolium Penn.). Revista Caatinga, v.20, n.4, p.34-37, 2007.

GIUSTI, M.M. \& WROLSTAD, R.E. Anthocyanins. Characterization and measurement of anthocyanins with UV-visible spectroscopy. In: WROLSTAD, R.E. (Ed.) Current Protocols in Food Analytical Chemistry. New York: John Wiley \& Sons, 2001. p F1.2.1-F1.2.13. GROSS, J. Anthocyanins. In: GROSS, J. Pigments in fruits. London: Academic Press, 1987. p. 59-85.

HE, J. \& GIUSTI, M.M. Anthocyanins: natural colorants with health-promoting properties. Annual Review of Food Science and Technology, v.1, p.163-187, 2010.

JIANG, L. et al. Characterization and activity of anthocyanins in zijuan tea (Camellia sinensis var. kitamura). Journal of Agricultural Food Chemistry, v.61, n.13, p.3306-3310, 2013.

KÄHKÖNEN, M.P. et al. Berry anthocyanins: isolation, identification and antioxidant activities. Journal of Agricultural Food Chemistry, v.83, n.14, p.1403-1411, 2003.
LIMA, V.L.A.G. et al. Fenólicos e carotenoides totais em pitanga. Scientia Agricola, v.59, n.3, p. 447-450, 2002.

LIMA, V.L.A.G. et al. Antioxidant capacity of anthocyanins from acerola genotypes. Ciência e Tecnologia de Alimentos, v.31, n.1, p.86-92, 2011.

LUCIOLI, S. Anthocyanins: Mechanism of action and therapeutic efficacy. In: CAPASSO, A. Medicinal plants as antioxidant agents: understanding their mechanism of action and therapeutic efficacy. Kerala: Research Signpost, 2012. p. 27-57.

MACHEIX, J.J. et al. The main phenolics of fruits. In: MACHEIX, J.J., FLEURIET, A., BILLOT, J. Fruit Phenolics. Boca Raton: CRC Press, 1990. p.1-103.

MILIAUSKAS G. et al. Screening of radical scavenging activity of some medicinal and aromatic plant extracts. Food Chemistry, v.85, n.2, p.231-237, 2004.

MURTHY, P.S. et al. Extraction, characterization and bioactivity of coffee anthocyanins. European Journal of Biological Sciences, v.4, n.1, p.13-19, 2012.

NAKAJIMA, J. et al. LC/PDA/ESI-MS profiling and radical scavenging activity of anthocyanins in various berries. Journal of Biomedicine and Biotechnology, v.5, p.241-247, 2004.

PAULINO, R.C. et al. Contribuição ao conhecimento e conservação da laranjinha. Interações, v.12, n.2, p. 215-223, 2011.

PROESTOS, C. et al. Antioxidant capacity of selected plant extracts and their essential oils. Antioxidants, v.2, n.1, p.11-22, 2013.

RODRIGUES, E. et al. Phenolic compounds and antioxidant activity of blueberry cultivars grown in Brazil. Ciência e Tecnologia de Alimentos, v. 31 n. 4, p.911-917, 2011

RODRIGUEZ-SAONA, L.E. \& WROLSTAD, R.E. Anthocyanins. Extraction, isolation, and purification of anthocyanins. In: WROLSTAD, R.E. (Ed.) Current Protocols in Food Analytical Chemistry. New York: John Wiley \& Sons, 2001. p. F1.1.1- F1.1.11.

RUFINO, M.S.M. et al. Free radical-scavenging behavior of some north-east Brazilian fruits in DPPH ${ }^{\circ}$ system. Food Chemistry, v.144, n.2, p.693-695, 2009.

SHARMA, O.P. \& BHAT, T.K. DPPH antioxidant assay revisited. Food Chemistry, v.113, n.4, p.1202-1205, 2009.

SHIPP, J. \& ABDEL-AAL, E-S. M. Food applications and physiological effects of anthocyanins as functional food ingredients. The Open Food Science Journal, v.4, p. 7-22, 2010.

SILVA, K.B. et al. Caracterização morfológica de frutos, sementes e germinação de Sideroxylon obtusifolium (Roem. e Schult.) Penn. (SAPOTACEAE). Revista Árvore, v.36, n.1, p.59-64, 2012. 